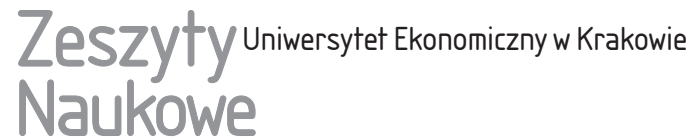

\author{
Małgorzata Kucia \\ Elżbieta Sikora
}

\section{Wpływ bazy kosmetycznej na uwalnianie kwasu usninowego}

\section{Streszczenie}

Kwas usninowy, należący do kwasów porostowych, odznacza się szerokim spektrum aktywności biologicznej, m.in. działa przeciwdrobnoustrojowo, przeciwzapalnie i promieniochronnie. Znajduje zastosowanie jako składnik leków roślinnych i produktów kosmetycznych. W pracy badano wpływ bazy kosmetycznej (typu emulsji i stopnia rozdrobnienia fazy wewnętrznej) na kinetykę uwalniania kwasu usninowego. Otrzymano dwa typy emulsji - O/W i W/O, o różnym stopniu rozdrobnienia fazy zdyspergowanej, zawierające $0,05 \% \mathrm{w} / \mathrm{w}$ kwasu usninowego. Dla otrzymanych produktów przeprowadzono badania właściwości fizykochemicznych (typ emulsji, stabilność, lepkość, pH, rozmiar kropli fazy zdyspergowanej). Badanie uwalniania kwasu usninowego przeprowadzono w układzie termostatowanych komór dyfuzyjnych, stosując błonę dializacyjną z regenerowanej celulozy. Jako roztwór akceptorowy zastosowano mieszaninę alkoholu etylowego i buforu fosforanowego (PBS) o $\mathrm{pH}=7,4 \mathrm{w}$ stosunku EtOH/PBS = 10/90 v/v. Stężenie uwolnionego kwasu analizowano za pomocą spektrofotometru UV-Vis. Uzyskane wyniki wykazały, że emulsje typu O/W w porównaniu z emulsjami typu W/O stanowią dużo skuteczniejszą formę podawania kwasu usninowego do skóry. Po 24 godz. z emulsji typu O/W przeniknęło do roztworu akceptorowego ok. 45\% stężenia początkowego kwasu, podczas gdy z emulsji typu W/O ok. $18 \%$.

Słowa kluczowe: kwas usninowy, baza kosmetyczna, proces przenikania, uwalnianie. Klasyfikacja JEL: L66.

Małgorzata Kucia, Uniwersytet Ekonomiczny w Krakowie, Wydział Towaroznawstwa i Zarządzania Produktem, Katedra Chemii Ogólnej, ul. Rakowicka 27, 31-510 Kraków, e-mail: malgorzata.kucia@uek.krakow.pl

Elżbieta Sikora, Politechnika Krakowska, Wydział Inżynierii i Technologii Chemicznej, Instytut Chemii i Technologii Organicznej, ul. Warszawska 24,31-155 Kraków, e-mail: esikora@ pk.edu.pl 


\section{Wprowadzenie}

Kwas usninowy (rys. 1) jest pochodną dibenzofuranu. W przyrodzie jego źródłem są porosty z rodzin: Cladonia, Usnea, Lecanora, Ramalina, Evernia, Parmelia, Alectoria i Flavocetrari [Caviglia i in. 2001, Bjerke i in. 2005, Barton, Deflorin i Edwards 1956].<smiles>CC(=O)C1=C(O)C=C2Oc3c(C(C)=O)c(O)c(C)c(O)c3[C@@]2(C)C1=O</smiles>

Rys. 1. Kwas (+)-usninowy

Źródło: [Kristmundsdóttir i in. 2005].

Kwas (+)-usninowy jest substancją charakteryzującą się szerokim spektrum aktywności biologicznej, wykazuje działanie przeciwdrobnoustrojowe, przeciwzapalne i promieniochronne [Caviglia i in. 2001, Ingólfsdóttir 2002, Honda i in. 2010, Grumezescu i in. 2011, König i Wright 1999, Perry i in. 1999, Kupchan i Kopperman 1975]. Jest aktywny wobec szczepów bakterii zarówno gram-dodatnich, jak i gram-ujemnych [Ingólfsdóttir 2002], w tym bakterii z rodzajów Streptococcus sp. (paciorkowce), Staphylococcus sp. (gronkowce), Pneumococcus sp. (dwoinka zapalenia płuc), Mycobacterium tuberculosis (prątek gruźlicy) [Grumezescu i in. 2011] i Streptococcus mutans (paciorkowiec odpowiedzialny m.in. za rozwój próchnicy) [Caviglia i in. 2001]. Wykazuje także aktywność przeciwgrzybiczą [Honda i in. 2010, König i Wright 1999, Perry i in. 1999] oraz przeciwpierwotniakową [Verotta i in 2007, Fournet $\mathrm{i}$ in. 1997]. Właściwości przeciwwirusowe kwasu usninowego nie są dokładnie zbadane, jednak z analiz przedstawionych w literaturze przedmiotu wynika, że związek ten wykazuje nieznaczną aktywność przeciwko wirusom HSV (Herpes Simple typu 1) i PSV1 (wirus polio typu 1) [König i Wright 1999, Studzińska-Sroka i Bylka 2010, Scirpa i in. 1999, Santos i in. 2006]. Coraz większe zainteresowanie naukowców wzbudza potencjalne działanie przeciwnowotworowe i antymutagenne niektórych porostów zawierających kwas usninowy [Kupchan i Kopperman 1975, Song i in. 2012]. Ponadto związek ten wykazuje działanie antyproliferacyjne wobec keratynocytów, co ma duże znaczenie $\mathrm{w}$ chorobach przebiegających $\mathrm{z}$ nadmierną keratynizacją 
naskórka [Zhong 2005]. Dzięki swoim właściwościom kwas usninowy znalazł zastosowanie jako składnik aktywny w preparatach kosmetycznych i farmaceutycznych. Stosowany jest jako składnik aktywny w kosmetykach dezodorujących, przeciwtrądzikowych oraz przeciwłupieżowych [Molski 2009, Moreira i in. 2013], a także w kosmetykach do higieny jamy ustnej, takich jak pasty do zębów czy płyny do płukania ust [Caviglia i in. 2001, Moreira i in. 2013, Safety Survey... 2010]. Znalazł również zastosowanie jako składnik produktów farmaceutycznych stosowanych w leczeniu łupieżu lub łuszczycy, a także w leczeniu oparzeń, ropni oraz malarii [Studzińska-Sroka i Bylka 2010, Safety Survey... 2010].

Efektywność działania preparatów kosmetycznych i farmaceutycznych stosowanych na skórę zależy od wielu czynników, w tym właściwości substancji przenikającej, rodzaju bazy kosmetyku i czynników biologicznych. Wśród właściwości substancji przenikającej istotne znaczenie mają wielkość i kształt cząsteczki, lipofilowość, rozpuszczalność, stopień dysocjacji, a także możliwość tworzenia wiązań chemicznych z komponentami struktury skóry. Kolejnym czynnikiem, który odgrywa znaczącą rolę, jest baza kosmetyku, tj. typ emulsji, obecność promotorów przenikania czy stopień rozdrobnienia fazy zdyspergowanej. Natomiast wśród czynników biologicznych znaczenie mają: grubość skóry, przepływ krwi, metabolizm, uwodnienie, obszar skóry, wiek, ale też choroby i stany zapalne [Molski 2009, 2013, Kaczmarzyk 2013, Arct, Majewski i Pytkowska 2008, Arct i Chełkowska 2001, Starzyk i Arct 2003, Jaworska, Sikora i Ogonowski 2011].

Celem pracy było zbadanie, w jakim stopniu na przenikanie kwasu usninowego, który jest substancją o charakterze lipofilowym, będzie miał wpływ typ zastosowanej jako baza emulsji, a także stopień rozdrobnienia fazy wewnętrznej. Kwestia ta wciąż jest przedmiotem dyskusji. $Z$ wielu analiz przedstawionych w literaturze przedmiotu wynika, że wielkość kropli fazy zdyspergowanej w istotny sposób wpływa na penetrację składników aktywnych [Otto, Du Plessis i Wiechers 2009, Paolino i in. 2002, Sonneville-Aubrun, Simonnet i L'Alloret 2004, Frelichowska i in. 2009, Kotyla i in. 2008], jednak z wcześniejszych badań autorów [Sikora i in. 2015], jak i z badań P. Izquierdo i współautorów [2007] wynika, że stopień dyspersji fazy wewnętrznej nie wpływa na przenikanie substancji aktywnych.

\section{Materiały i metody badań}

\subsection{Uwagi ogólne}

Na podstawie opracowanych receptur (tabela 1$)$ przygotowano emulsje $(\mathrm{O} / \mathrm{W}$ i W/O) zawierające jako składnik aktywny kwas usninowy (Aldrich) o stężeniu $0,05 \%$. Jako fazę olejową w emulsjach oraz jako olej odniesienia zastosowano triglicerydy krótkołańcuchowych kwasów tłuszczowych (Crodamol GTCC - 
Croda). W fazie wodnej emulsji jako składnik nawilżający zastosowano glicerynę (POCh S.A). Lepkość emulsji regulowano poprzez dodatek gumy ksantanowej (Regis), a w przypadku emulsji typu W/O dodatkowo poprzez dodatek wosku pszczelego (Pharma Cosmetics). Jako środek konserwujący zastosowano benzoesan sodu (Pharma Cosmetics). Emulsje stabilizowano, stosując w przypadku emulsji typu O/W Arlacel 2121 (Croda), a w przypadku emulsji typu W/O Isolan GI34 (Evonik).

Tabela 1. Skład ilościowy opracowanych receptur emulsji

\begin{tabular}{|l|l|c|c|}
\hline \multirow{2}{*}{ Składnik } & \multicolumn{2}{c|}{ Nazwa INCI } & \multicolumn{2}{c|}{ Skład, \% mas. } \\
\cline { 3 - 4 } & & $\mathrm{E}_{1}(\mathrm{~W} / \mathrm{O})$ & $\mathrm{E}_{2}(\mathrm{O} / \mathrm{W})$ \\
\hline Arlacel 2121 & $\begin{array}{l}\text { Sorbitan Stearate } \\
\text { and Sucrose Cocoate }\end{array}$ & - & 5 \\
\hline Isolan GI 34 & Polyglyceryl-4 Isostearate & 4 & - \\
\hline Crodamol GTCC & Caprylic/Capric Trigliceride & 17 & 17 \\
\hline Wosk biały & Cera alba & 3 & - \\
\hline Kwas usninowy & (+)-Usnic acid 98\% & 0,05 & 0,05 \\
\hline Gliceryna bezwodna & Glycerin & 3 & 3 \\
\hline Guma ksantanowa & Xantham gum & 0,5 & 0,5 \\
\hline Benzoesan sodu & Benzoesic acid & 0,5 & 0,5 \\
\hline Woda & Aqua & do 100 & do 100 \\
\hline
\end{tabular}

Źródło: opracowanie własne.

Przygotowując emulsje $\mathrm{E}_{1}(\mathrm{~W} / \mathrm{O}) \mathrm{i}_{2}(\mathrm{O} / \mathrm{W})$ postępowano według standardowej procedury: połączone składniki, oddzielnie fazy olejowej i wodnej, podgrzano do temperatury $65^{\circ} \mathrm{C}$ w celu uzyskania klarownych cieczy. Kwas usninowy wprowadzano do fazy olejowej. Następnie obie fazy łączono na ciepło $\left(T=65^{\circ} \mathrm{C}\right)$, wlewając fazę wewnętrzną do fazy ciągłej, całość mieszano z prędkością 600 obrotów na minutę (rpm), stosując mieszadło mechaniczne firmy IKA ${ }^{\circledR}$, przez 15 min. Po połączeniu faz mieszanie kontynuowano, chłodząc masę emulsyjną do temperatury $T=25^{\circ} \mathrm{C}$. W celu uzyskania produktów o większym stopniu zdyspergowania fazy wewnętrznej, $\mathrm{E}_{3}(\mathrm{~W} / \mathrm{O})$ i $_{4}(\mathrm{O} / \mathrm{W})$, przygotowano próbki emulsji według powyżej opisanej procedury, które następnie poddano procesowi homogenizacji (czas homogenizacji $t=2 \mathrm{~min}$, szybkość homogenizacji $v=12000 \mathrm{rpm}$. W badaniach użyto homogenizatora firmy CAT Scientific. Wszystkie otrzymane emulsje poddano ocenie pod względem właściwości fizykochemicznych. Stabilność badanych produktów oceniano, stosując metodę wirówkową i test zmiennych temperatur. W pierwszym przypadku próbki emulsji umieszczone w wirówce 
(wirówka firmy Hettich Zenttrifugem) wirowano z szybkością 3000 rpm w czasie 30 min. Testy temperaturowe przeprowadzono metodą szoków termicznych, umieszczając próbki emulsji najpierw w temperaturze $T=40^{\circ} \mathrm{C}$, a następnie w $T=4^{\circ} \mathrm{C}$, w czasie 48 godz. Typ emulsji badano metodą rozcieńczeń oraz za pomocą pomiaru przewodnictwa elektrycznego (konduktometr firmy Mettler Toledo). Pomiar pH wykonano, stosując pH-metr firmy Mettler Toledo. Wielkość kropli fazy zdyspergowanej zmierzono za pomocą mikroskopu optycznego firmy Motic, z torem wizyjnym, sterowanego komputerowo (program Motic images Plus 2.0 ML). Na zarejestrowanych zdjęciach mikroskopowych przeprowadzono autokalkulację kropli i na tej podstawie wyliczono średnią średnicę kropli (średnica stanowiła wartość średnią z 900 do 1200 zliczeń). Do pomiaru lepkości sporządzonych emulsji użyto reometru rotacyjnego model R/S Plus firmy Brookfield, wyposażonego w układ pomiarowy typu stożek-płytka. Czystość mikrobiologiczną badanych preparatów sprawdzono, stosując testy Microcount Combi firmy Schülke. Badanie prowadzono według procedury polecanej przez producenta (http://www.schuelke.com/download/pdf/cint_lde-gb_mikrocount_combi_fol.pdf, data dostępu: 5.05.2016).

\subsection{Badanie uwalniania kwasu usninowego}

Badania kinetyki uwalniania kwasu usninowego z opracowanych formulacji: $\mathrm{E}_{1}(\mathrm{~W} / \mathrm{O}), \mathrm{E}_{2}(\mathrm{O} / \mathrm{W}), \mathrm{E}_{3}(\mathrm{~W} / \mathrm{O}), \mathrm{E}_{4}(\mathrm{O} / \mathrm{W})$ zostało przeprowadzone na układach modelowych, w systemie trzech termostatowanych komór dyfuzyjnych, w temperaturze $32^{\circ} \mathrm{C}$ przez okres 24 godz. Roztwór akceptora stanowiła mieszanina alkoholu etylowego i buforu fosforanowego (PBS) o $\mathrm{pH}=7,4$, w stosunku EtOH/PBS = $=10 / 90 \mathrm{v} / \mathrm{v}$. Do badań zastosowano membrany dializacyjne Spectra/Por Standard Regenerated Cellulose (RC) (MWCO 6-8). Jako próbkę odniesienia zastosowano 0,05-procentowy roztwór kwasu usninowego w Crodamol GTCC. Analizę jakościową i ilościową substancji aktywnej w roztworze akceptora przeprowadzono za pomocą spektrofotometru Nanocolor UV-VIS firmy Machery-Nagel. Stężenie kwasu usninowego w roztworze akceptorowym obliczono na podstawie wstępnie wyznaczonej krzywej kalibracji $\left(R^{2}=0,999\right.$, gdzie $R^{2}$ - współczynnik determinacji liniowej), zgodnie z równaniem:

$$
y=93,826 x+0,172,
$$

gdzie:

$y$ - absorbancja przy długości fali $\lambda=291,5 \mathrm{~nm}$,

$x$ - stężenie $\mathrm{w} \mathrm{mg} / \mathrm{cm}^{3}$. 


\section{Wyniki i dyskusja wyników}

\subsection{Charakterystyka badanych emulsji}

W tabeli 2 przedstawiono wyniki pomiarów właściwości otrzymanych preparatów. Z zamieszczonych danych wynika, że opracowano stabilne emulsje zawierające jako składnik aktywny kwas usninowy. Zgodnie z założeniami, w zależności od rodzaju zastosowanego emulgatora uzyskano dwa różne typy emulsji - W/O i O/W. Zastosowanie dodatkowo procesu homogenizacji pozwoliło na uzyskanie emulsji o większym stopniu rozdrobnienia fazy wewnętrznej, o średnicach kropel średnio mniejszych o ok. $3 \mu \mathrm{m}$ od średnicy kropel w emulsjach niehomogenizowanych. Ponadto na podstawie przedstawionych na fot. 1 i 2 przykładowych zdjęć mikroskopowych można zauważyć, że proces homogenizacji pozwolił na uzyskanie bardziej jednorodnych układów.

Tabela 2. Właściwości fizykochemiczne sporządzonych emulsji

\begin{tabular}{|c|c|c|c|c|c|}
\hline \multirow[b]{2}{*}{ Emulsja } & \multicolumn{2}{|c|}{ Stabilność } & \multicolumn{2}{|c|}{ Typ emulsji } & \multirow[b]{2}{*}{$\begin{array}{l}\text { Srednia śred- } \\
\text { nica kropel } \\
\text { fazy zdysper- } \\
\text { gowanej } d, \mu \mathrm{m} \\
\quad(n=900)\end{array}$} \\
\hline & $\begin{array}{c}\text { metoda } \\
\text { wirówkowa }\end{array}$ & $\begin{array}{c}\text { metoda } \\
\text { szoków } \\
\text { termicznych } \\
\text { (temperatury } \\
0^{\circ} \mathrm{C} \mathrm{i} 40^{\circ} \mathrm{C} \text { ) }\end{array}$ & $\begin{array}{c}\text { metoda } \\
\text { rozcieńczeń }\end{array}$ & $\begin{array}{c}\text { metoda } \\
\text { konduktome- } \\
\text { tryczna, } \\
\mu \mathrm{S} / \mathrm{cm}\end{array}$ & \\
\hline $\mathrm{E}_{1}(\mathrm{O} / \mathrm{W})$ & + & + & $\mathrm{O} / \mathrm{W}$ & 1280 & $10,9( \pm 1,92)$ \\
\hline $\mathrm{E}_{2}(\mathrm{~W} / \mathrm{O})$ & + & + & $\mathrm{W} / \mathrm{O}$ & 0,079 & $9,5( \pm 1,64)$ \\
\hline $\mathrm{E}_{3}(\mathrm{O} / \mathrm{W})$ & + & + & $\mathrm{O} / \mathrm{W}$ & 1280 & $7,4( \pm 0,65)$ \\
\hline $\mathrm{E}_{4}(\mathrm{~W} / \mathrm{O})$ & + & + & $\mathrm{W} / \mathrm{O}$ & 0,079 & $5,4( \pm 0,55)$ \\
\hline
\end{tabular}

Objaśnienia: + emulsja stabilna, $\mathrm{E}_{1}(\mathrm{O} / \mathrm{W}), \mathrm{E}_{2}(\mathrm{~W} / \mathrm{O})$ - emulsje niehomogenizowane, $\mathrm{E}_{3}(\mathrm{O} / \mathrm{W}), \mathrm{E}_{4}(\mathrm{~W} / \mathrm{O})$ - emulsje homogenizowane.

Źródło: opracowanie własne.

Wszystkie otrzymane preparaty miały wartości $\mathrm{pH}$ odpowiadające fizjologicznemu pH skóry $(5,9-6,1)$. Wyniki badań przeprowadzonych z użyciem testu Microcount Combi potwierdziły czystość mikrobiologiczną badanych preparatów. W żadnym przypadku, po odpowiednim okresie inkubacji, na pożywkach agarowych znajdujących się na płytkach pomiarowych nie obserwowano obecności grzybów i bakterii. 


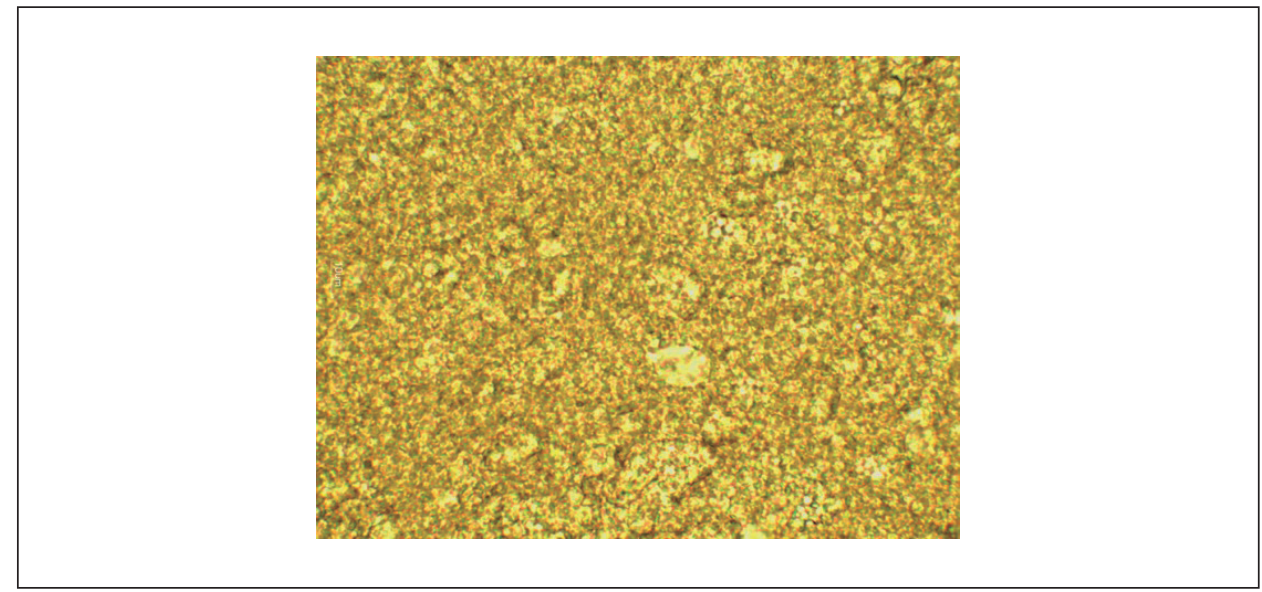

Fot. 1. Obraz mikroskopowy emulsji typu W/O przed homogenizacją $-\mathrm{E}_{2}(\mathrm{~W} / \mathrm{O})$

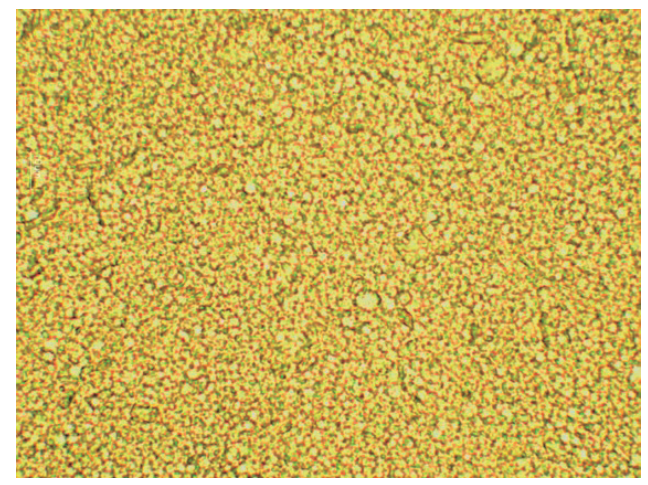

Fot. 2. Obraz mikroskopowy emulsji typu W/O po homogenizacji $-\mathrm{E}_{4}(\mathrm{~W} / \mathrm{O})$

Na rys. 2 przedstawiono krzywe lepkości badanych emulsji. Na podstawie zamieszczonych danych można stwierdzić, że otrzymane produkty należą do cieczy nienewtonowskich, pseudoplastycznych, rozrzedzanych ścinaniem oraz że proces homogenizacji powoduje wzrost lepkości preparatów w całym badanym zakresie szybkości ścinania, przy czym zmiana ta jest bardziej wyraźna w przypadku emulsji typu W/O. 


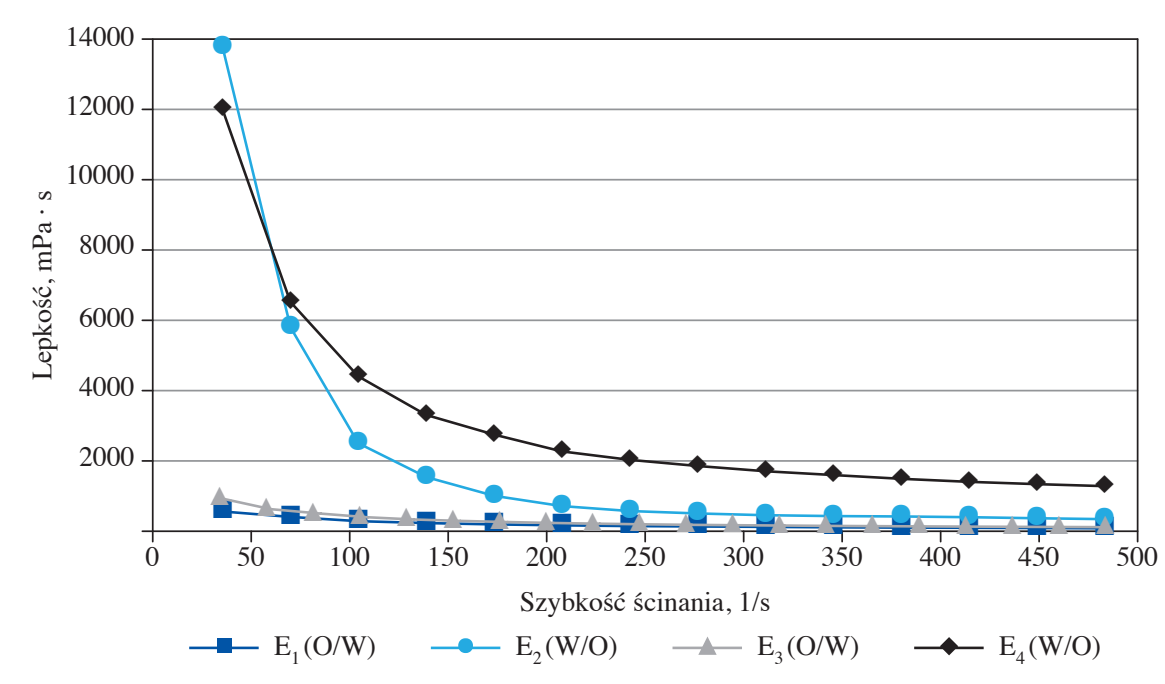

Rys. 2. Zależność lepkości dynamicznej od szybkości ścinania dla badanych emulsji Źródło: opracowanie własne.

\subsection{Uwalnianie kwasu usninowego}

Na rys. 3 przedstawiono widmo absorpcyjne (UV-Vis) w roztworze akceptorowym $($ EtOH/PBS $=10 / 90 \mathrm{v} / \mathrm{v})$. Na rysunku widoczne są dwa maksima absorbcyjne, przy długości fali $\lambda=226 \mathrm{~nm}$ oraz $\lambda=291,5 \mathrm{~nm}$, które są charakterystyczne dla kwasu usninowego [Osterrothowa i Jehlicka 2009]. W przypadku analizy zawartości kwasu usninowego w próbkach roztworu akceptorowego, pobieranych w czasie testu uwalniania, do obliczenia stężenia kwasu odczytywano wartości absorbancji dla długości fali $\lambda=291,5 \mathrm{~nm}$. Na rys. 4 przedstawiono przykładowe widma UV-vis dla kwasu usninowego w próbce roztworu akceptorowego pobranej do analizy po 19 godz. uwalniania.

Na rys. 5 przedstawiono krzywe uwalniania kwasu usninowego z emulsji olej w wodzie $\left(\mathrm{E}_{1}(\mathrm{O} / \mathrm{W})\right.$ i $\left.\mathrm{E}_{3}(\mathrm{O} / \mathrm{W})\right)$ oraz woda w oleju $\left(\mathrm{E}_{2}(\mathrm{~W} / \mathrm{O})\right.$ i $\left.\mathrm{E}_{4}(\mathrm{~W} / \mathrm{O})\right)$, a także z bazy olejowej (Crodamolu GTCC). Na podstawie zamieszczonych danych można zauważyć, że forma fizykochemiczna receptury bazowej, w której umieszczona jest substancja czynna, wpływa na kinetykę uwalniania kwasu usninowego. Kwas usninowy lepiej (efektywniej) jest uwalniany z emulsji typu O/W, następnie z bazy olejowej, a najwolniej z emulsji typu W/O. Odpowiednio po 24 godz. z emulsji $\mathrm{E}_{1}(\mathrm{O} / \mathrm{W})$ przeniknęło do roztworu akceptorowego $11,7 \mu \mathrm{g} / \mathrm{cm}^{3} \mathrm{kwasu}$ (co stanowi $44,12 \%$ stężenia początkowego), w przypadku oleju $7,11 \mu \mathrm{g} / \mathrm{cm}^{3}(22,92 \%$ stężenia początkowego), natomiast w przypadku emulsji $\mathrm{E}_{2}(\mathrm{~W} / \mathrm{O})-3,99 \mu \mathrm{g} / \mathrm{cm}^{3}$ 


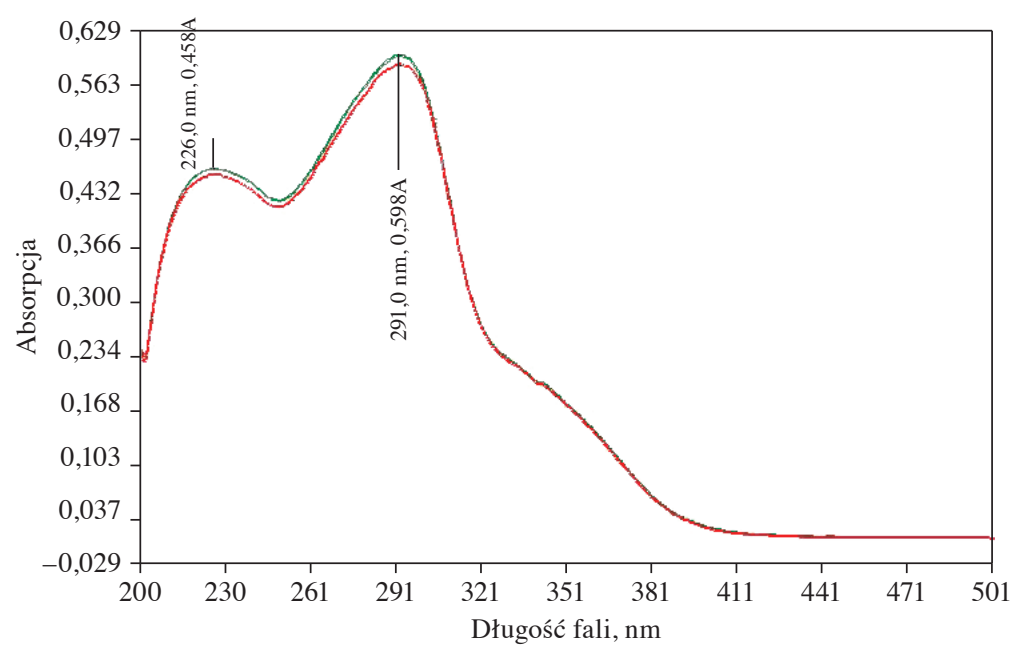

Rys. 3. Widmo UV-vis dla kwasu usninowego w roztworze EtOH/PBS Źródło: opracowanie własne.

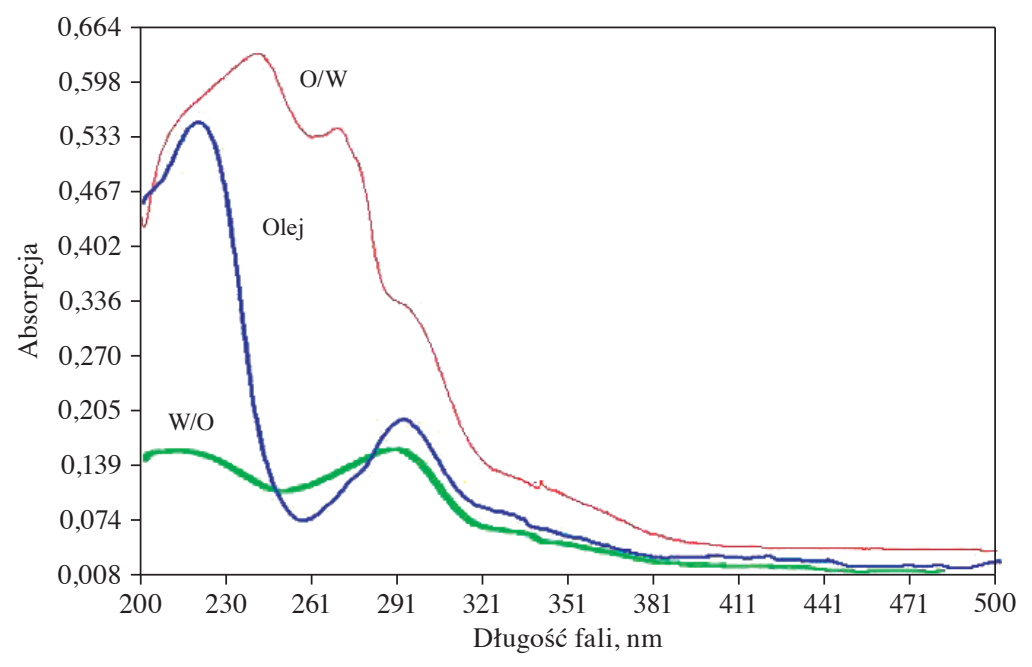

Objaśnienia: O/W - roztwór akceptorowy zawierający kwas usninowy uwalniany z emulsji O/W, Olej - roztwór akceptorowy zawierający kwas usninowy uwalniany z Crodamolu GTCC, W/O - roztwór akceptorowy zawierający kwas usninowy uwalniany z emulsji W/O

Rys. 4. Widmo próbki kwasu usninowego w roztworzie akceptorowym (EtOH/PBS) pobranej po 19 godz. uwalniania

Źródło: opracowanie własne. 
(co stanowi 18,16\% stężenia początkowego). Zgodnie z wynikami wcześniejszych badań autorów, stopień rozdrobnienia fazy wewnętrznej nie wpłynął w znacznym stopniu na stężenie uwolnionego kwasu usninowego. Gdy porównamy ilość kwasu, która przenikała z emulsji $\mathrm{O} / \mathrm{W}$ niehomogenizowanej $\mathrm{E}_{1}(\mathrm{O} / \mathrm{W})(d=10,7 \mu \mathrm{m})$ i po homogenizacji $\mathrm{E}_{3}(\mathrm{O} / \mathrm{W})(d=7,4 \mu \mathrm{m})$, odpowiednio $44,12 \%$ i $45,25 \%$ stężenia początkowego, a także $\mathrm{E}_{2}(\mathrm{~W} / \mathrm{O})(d=9,57 \mu \mathrm{m})$ i $_{4}(\mathrm{~W} / \mathrm{O})(d=5,4 \mu \mathrm{m})-18,16 \%$ i 15,63\% stężenia początkowego kwasu, widoczne jest, że stopień zdyspergowania fazy wewnętrznej emulsji nie wpływa na końcową ilość uwolnionego kwasu. W przypadku emulsji typu W/O oba profile uwalniania kwasu mają zbliżony przebieg w czasie całego pomiaru. W przypadku emulsji typu O/W w czasie pierwszych 5 godz. procesu oraz po 20 godz., profile uwalniania kwasu mają również zbliżony kształt.

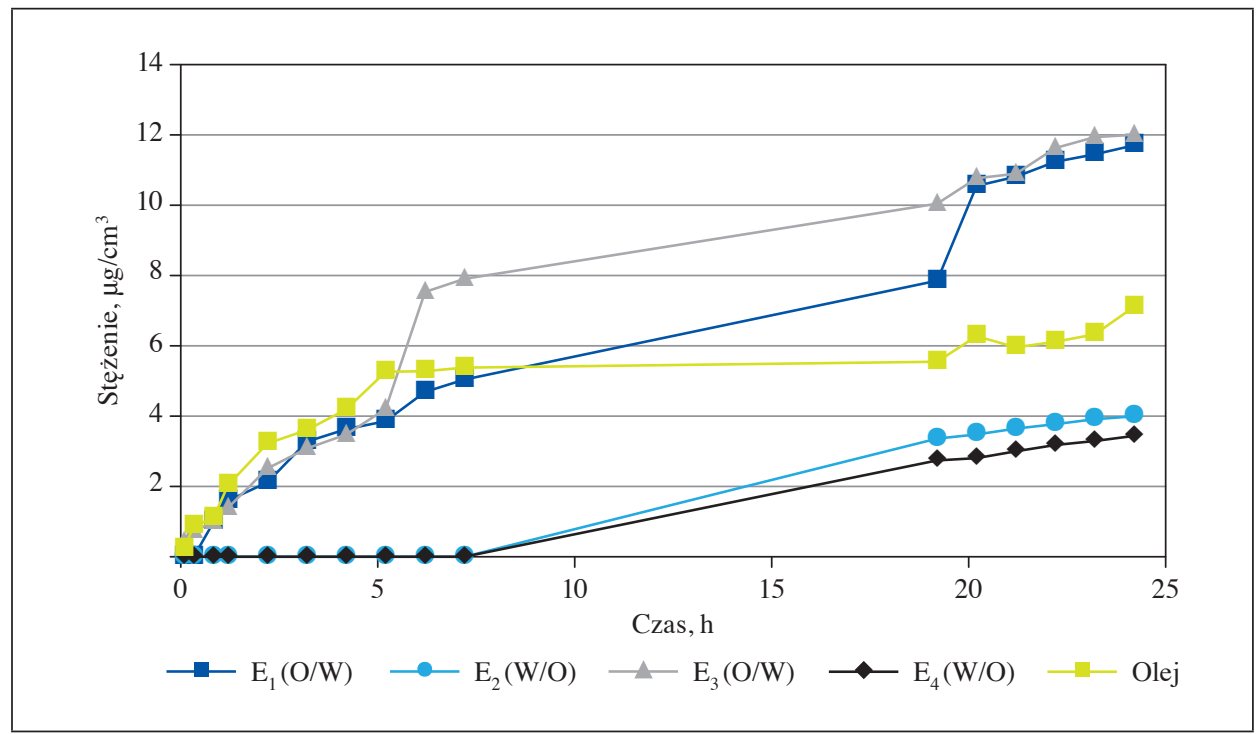

Rys. 5. Wpływ formulacji bazowej na uwalnianie kwasu usninowego Źródło: opracowanie własne.

Obserwowane zależności związane są prawdopodobnie w dużym stopniu z właściwościami kwas usninowego. Związek ten jest substancją o charakterze hydrofobowym i dlatego emulsje typu W/O stanowią dla niego mniej efektywny nośnik. Lipofilowy kwas usninowy zawarty w fazie ciągłej (olejowej) emulsji ze względu na swoją lipofilowość gorzej przenika do hydrofilowego roztworu akceptorowego. Z pewnością na efektywność uwalnia będzie również wpływać różnica w lepkościach formulacji; emulsje woda w oleju $\left(\mathrm{E}_{2}(\mathrm{~W} / \mathrm{O})\right.$ i $\left.\mathrm{E}_{4}(\mathrm{~W} / \mathrm{O})\right)$ w porównaniu z emulsjami olej w wodzie $\left(\mathrm{E}_{1}(\mathrm{O} / \mathrm{W})\right.$ i $\left.\mathrm{E}_{3}(\mathrm{O} / \mathrm{W})\right)$ charakteryzo- 
wały się znacznie większą lepkością w całym zakresie szybkości ścinania (rys. 2), co zgodnie z prawem Stokesa-Einsteina wpływa na proces dyfuzji substancji aktywnej.

\section{Podsumowanie}

Kwas usninowy ze względu na właściwości antybakteryjne i przeciwzapalne może znaleźć zastosowanie w preparatach przeciwtrądzikowych, przeciwłupieżowych, a także w preparatach do pielęgnacji skóry atopowej czy w leczeniu innych dermatoz skórnych. Efektywność działania preparatów kosmetycznych i farmaceutycznych stosowanych na skórę zależy od wielu czynników, w tym właściwości substancji przenikającej czy rodzaju bazy kosmetyku. Wyniki przeprowadzonych badań potwierdziły, że stopień rozdrobnienia fazy rozproszonej w emulsjach w niewielkim stopniu wpływał na proces uwalniania kwasu usninowego. Bez względu na różnicę w rozmiarach kropel fazy wewnętrznej uzyskano podobny profil uwalniania substancji czynnej zwłaszcza w końcowej fazie procesu. Natomiast wyraźnie na proces uwalniania kwasu usninowego wpływa typ emulsji, w której zawarty był związek. Różnice obserwowano już po pierwszych 5 godz. procesu uwalniania kwasu z badanych emulsji, natomiast po 24 godz. różnice w ilości kwasu uwolnionego do roztworu akceptorowego były bardzo wyraźne. $\mathrm{Z}$ emulsji typu O/W przeniknęło do roztworu akceptorowego ok. $45 \%$ zawartego w formulacji kwasu usninowego, podczas gdy z emulsji typu W/O ok. 18\% stężenia początkowego. Posumowując, emulsje typu O/W w porównaniu z emulsjami typu W/O stanowiły dużo skuteczniejszą formę podawania kwasu usninowego do skóry.

\section{Literatura}

Arct J., Chełkowska M. [2001], Czy możliwe jest przewidywanie zdolności wnikania w skórę aktywnych składników produktów kosmetycznych?, „Wiadomości Polskiego Towarzystwa Kosmetologów”, nr 3/4.

Arct J., Majewski S., Pytkowska K. [2008], Kosmetyczne zastosowanie witamin A $i$ E. Pielęgnacja i suplementacja, Wyższa Szkoła Zawodowa Kosmetyki i Pielęgnacji Zdrowia, Warszawa.

Barton H.D.R., Deflorin A.M., Edwards O.E. [1956], The Synthesis of Ursenic Acid, „Journal of the Chemical Society (Resumed)”, https://doi.org/10.1039/jr9560000530.

Bjerke J.W., Elvebakk A., Dominguez E., Dahlback A. [2005], Seasonal Trends in Usnic Acid Concentrations of Arctic, Alpine and Patagonian Populations of the Lichen Flavocetraria nivalis, „Phytochemistry”, vol. 66, nr 3, https://doi.org/10.1016/j.phytochem.2004.12.007. 
Caviglia A.M., Nicora P., Giordani P., Brunialti G., Mondenesi P. [2001], Oxidative Stress and Usnic Acid Content in Parmelia caperata and Parmelia soredians, „Farmaco”, vol. 56, nr 5-7, https://doi.org/10.1016/S0014-827X(01)01090-4.

Fournet A., Ferreira M.E., Rojas de Arias A., Torres de Ortiz S., Inchausti A., Yaluff G., Quilhot W., Fernandez E., Hidalgo M.E. [1997], Activity of Compounds Isolated from Chilean Lichens against Experimental Cutaneous Ieishmaniasis, „Comparative Biochemistry and Physiology Part C: Pharmatology, Toxicology \& Endocrinology", vol. 116, nr 1, https://doi.org/10.1016/s0742-8413(96)00127-2.

Frelichowska J., Bolzinger M.A., Pelletier J., Valour J.P., Chevalier Y. [2009], Topical Delivery of Lipophilic Drugs From o/w Pickering Emulsions, ,International Journal of Pharmaceutics", vol. 371, nr 1-2, https://doi.org/10.1016/j.ijpharm.2008.12.017.

Grumezescu A.M., Saviuc C., Chifiriuc M.C., Hristu R., Mihaiescu D.E., Balaure P., Stanciu G., Lazar V. [2011], Inhibitory Activity of $\mathrm{Fe}_{3} \mathrm{O}_{4} /$ Oleic Acid/Usnic Acid-Corel Shell Nanofluid on. S.aureus Biofil Development, „IEE Transaction on NanoBioscence", vol. 10, nr 4, https://doi.org/10.1109/tnb.2011.2178263.

Honda N.K., Pavan F.R., Coelho R.G., de Andrade Leite S.R., Micheletti A.C., Lopes T.I.B., Misutsu M.Y., Beatriz A., Brum R.L., Leite C.Q.F. [2010], Antimycobacterial Activity of Lichen Substances, „Phytomedicine”, vol. 17, nr 5, https://doi.org/10.1016/ j.phymed.2009.07.018.

Ingólfsdóttir K. [2002], Usnic Acid, „Phytochemistry”, vol. 61, nr 7, https://doi.org/10.1016/ s0031-9422(02)00383-7.

Izquierdo P., Wiechers J.W., Escribano E., Garcia-Celma M.J., Tadros T.F., Esquena J., Dederen J.C., Solans C. [2007], A Study on the Influence of Emulsion Droplet Size on the Skin Penetration of Tetracaine, ,Skin Pharmacology and Physiology”, vol. 20, nr 5, https://doi.org/10.1159/000106076.

Jaworska M., Sikora E., Ogonowski J. [2011], Czynniki wpływajace na penetracje składników aktywnych przez skórę, „Wiadomości Chemiczne”, nr 3-4.

Kaczmarzyk D. [2013], Kosmetyki wyszczuplajqce - skuteczne działanie czy marketing?, „Kosmetologia Estetyczna”, nr 2(4).

König G.M., Wright A.D. [1999], $1 H$ and 13C-NMR and Biological Activity Investigations of Four Lichen-derived Compounds, „Phytochemical Analysis”, vol. 10, nr 5, https:// doi.org/10.1002/(sici)1099-1565(199909/10)10:5<279::aid-pca464>3.3.co;2-v.

Kotyla T., Kuo F., Moolchandani V., Wilson T., Nicolosi R. [2008], Increased Bioavailability of a Transdermal Application of a Nano-sized Emulsion Preparation, „International Journal of Pharmaceutics”, vol. 347, nr 1-2, https://doi.org/10.1016/ j.ijpharm.2007.06.045.

Kristmundsdóttir T., Jónsdóttir E., Ögmundsdóttir H., Ingólfdóttir K. [2005], Solubilization of Poorly Soluble Lichen Metabolites for Biological Testing on Cell Lines, „European Journal of Pharmaceutical Sciences”, vol. 24, nr 5, https://doi.org/10.1016/ j.ejps.2005.01.011.

Kupchan S.M., Kopperman H.L. [1975], l-Usnic Acid: Tumour Inhibition Isolated from Lichens, „Experientia”, vol. 31, nr 6, https://doi.org/10.1007/bf01944592.

Molski M. [2009], Chemia piękna, Wydawnictwo Naukowe PWN, Warszawa.

Molski M. [2013], Nowoczesne składniki kosmetyków, Wydawnictwo Kosmoprof, Poznań.

Moreira C., Oliveira A., Comar J., Peralta R., Bracht A. [2013], Harmful Effects of Usnic Acid on Hepatic Metabolism, „Chemico-Biological Interactions”, vol. 203, nr 2, https:// doi.org/10.1016/j.cbi.2013.02.001. 
Osterrothowa K., Jehlicka J. [2009], Raman Sectroscopic Identification of Usnic Acid in Hydrothermal Minerals as a Potential Martian Analogue, ,Spectrochimica Acta. Part A: Molecular and Biomolecular Spectroscopy”, vol. 73, nr 3, https://doi.org/10.1016/ j.saa.2008.09.005.

Otto A., Du Plessis J., Wiechers J. W. [2009], Formulation Effects of Topical Emulsions on Transdermal and Dermal Delivery, ,International Journal of Cosmetic Science”, vol. 31, nr 1, https://doi.org/10.1111/j.1468-2494.2008.00467.x.

Paolino D., Ventura C.A., Nistico S., Puglisi G., Fresta M. [2002], Lecithin Microemulsions for the Topical Administration of Ketoprofen: Percutaneous Adsorption through Human Skin and in Vivo Human Skin Tolerability, ,International Journal of Pharmaceutics", vol. 244, nr 1-2, https://doi.org/10.1016/s0378-5173(02)00295-8.

Perry N.B., Benn M.H., Brennan N.J., Burgess E.J., Ellis G., Galloway D.J., Lorimer S.D., Tangney R.S. [1999], Antimicrobial, Antiviral and Cytotoxic Activity of New Zeland Lichen, „The Lichenologist”, vol. 31, nr 6, https://doi.org/10.1006/lich.1999.0241.

Safety Survey of Active Ingredients Used in Cosmetics [2010], Committee of Experts on Cosmetics Products, Council of Europe, Strasburg.

Santos N. P. S., Nascimento S. C., Wanderley M. S. O., Pontes-Filho N. T., Silva J. F., Castro C. M. M. B., Pereira E. C., Silva N. H., Honda N. K., Santos-Magalhães N. S. [2006], Nanoencapsulation of Usnic Acid: An Attempt to Improve Antitumor Activity and Reduce Hepatotoxicity, ,European Journal of Pharmaceutics and Biopharmaceutica", nr 2.

Scirpa P., Scambia G., Masciullo V., Battaglia F., Foti E., Lopez R., Villa P., Malecore M., Mancuso S. [1999], A Zinc Sulfate and Usnic Acid Preparation Used as Post-surgical Adjuvant Therapy in Genital Lesions by Human Papillomavirus, ,Minerva Ginecolica", nr 51(6).

Sikora E., Llinas M., Garcia-Celma M.J., Escribano E., Solans C. [2015], Transdermal Delivery of Forskolin from Emulsions Differing in Droplet Size, „Coloids and Surfaces B: Biointerfaces”, vol. 26, https://doi.org/10.1016/j.colsurfb.2015.01.008.

Song Y., Dai F., Zhai D., Dong Y., Zhang J., Lu B., Luo J., Liu M., Yi Z. [2012], Usnic Acid Inhibits Breast Tumor Angiogenesis and Growth by Suppressing VEGFR2-mediated AKT and ERK1/2 Signaling Pathways, ,Angiogenesis”, vol. 15, nr 3, https://doi. org/10.1007/s10456-012-9270-4.

Sonneville-Aubrun O., Simonnet J.T., L'Alloret F. [2004], Nanoemulsion: a New Vehicle for Skin Care Products, „Advances in Colloid and Interface Science”, vol. 108-109, https://doi.org/10.1016/j.cis.2003.10.026.

Starzyk E., Arct J. [2003], Liofilowość i absorpcja przez naskórkowa w kosmetykach, „Wiadomości Polskiego Towarzystwa Kosmetologów”, nr 3.

Studzińska-Sroka E., Bylka W. [2010], Aktywność przeciwdrobnoustrojowa metabolitów wtórnych porostów, „Postępy Fitoterapii”, nr 1.

Verotta L., Appendino G., Bombardelli E., Brun R. [2007], In Vitro Antimalarial Activity of Hyperforin, a Prenylated Acylphloroglucinol. A Structure-activity Study, „Bioorganic \& Medicinal Chemistry Letters”, vol. 17, nr 6, https://doi.org/10.1016/ j.bmcl.2006.12.100.

Zhong Y.C. [2005], The Study on Skin Wound Healing Promoting Action of Sodium Usnic Acid, ,Journal of Chinese Medicinal Materials”, vol. 28(2). 


\section{The Influence of Cosmetics Bases on the Release of Usnic Acid}

(Abstract)

Usnic acid is a type of lichen acid which exhibits a broad spectrum of biological activity, functioning as an antimicrobial, an anti-inflammatory and a UV-filter. It is used as an active ingredient in herbal medicines and cosmetics products. Its influence as a cosmetics base, including through properties such as emulsion type or degree of internal phase droplet size, on the release of usnic acid, was studied. Two types $(\mathrm{O} / \mathrm{W}, \mathrm{W} / \mathrm{O})$ of usnic acid - loaded, stable emulsions with varying degrees of dispersion of the dispersed phase were obtained. The concentration of usnic acid in all of the formulations studied was $0.05 \%$ $\mathrm{w} / \mathrm{w}$. The formulations' physicochemical properties, including stability, viscosity, $\mathrm{pH}$ and the droplet size of the dispersed phase, were evaluated. The kinesis of the usnic acid's release was performed in a thermostatic diffusion chamber, at a temperature of $T=32^{\circ} \mathrm{C}$, using dialysis membranes of regenerated cellulose. A mixture of phosphate buffer (PBS) and ethanol (EtOH), in 90/10, PBS/EtOH, volume ratio, was used as an acceptor solution. The concentration of released usnic acid was analyzed by UV-Vis spectrophotometer. The results showed that the $\mathrm{O} / \mathrm{W}$ emulsions, as compared to $\mathrm{W} / \mathrm{O}$ emulsions, are a much more effective means of administering usnic acid to the skin. After 24 hours, approx. $45 \%$ of the initial acid concentration penetrated into the acceptor solution from $\mathrm{O} / \mathrm{W}$ emulsion, while from the $\mathrm{W} / \mathrm{O}$ emulsion the released amount was about $18 \%$.

Keywords: usnic acid, base cosmetic, process of diffusion, release. 